\title{
Macroecology of population dynamics and life history traits of the mole crab Emerita brasiliensis in Atlantic sandy beaches of South America
}

\author{
Omar Defeo ${ }^{1,2, *}$, Ricardo S. Cardoso ${ }^{3}$ \\ ${ }^{1}$ Centro de Investigación y de Estudios Avanzados, Unidad Mérida, Carretera Antigua a Progresso km 6, PO Box 73, \\ Cordemex, 97310 Mérida, Yucatán, Mexico \\ ${ }^{2}$ Unidad de Ciencias del Mar (UNIDECIMAR), Facultad de Ciencias, Iguá 4225, PO Box 10773, 11400 Montevideo, Uruguay \\ ${ }^{3}$ Laboratorio de Dinâmica de Populações Marinhas, Depto. Ciências Naturais, Universidade do Rio de Janeiro (UNIRIO), \\ Av. Pasteur no. 296, Urca, Rio de Janeiro, RJ, CEP 22290-240, Brazil
}

\begin{abstract}
Several studies have shown consistent macroinfauna community patterns in sandy beaches that could be mainly explained by variations in physical factors (i.e. grain size, beach slope, swash processes). However, the macroecology of population dynamics and biogeographic patterns in life history traits have not been adequately assessed in sandy beach ecology. Here, we examine the latitudinal variation of population dynamics and life history traits of the sandy intertidal mole crab Emerita brasiliensis in sandy beaches along the entire range of the species distribution of some $2700 \mathrm{~km}$ of the Atlantic coast of South America. Population structure by sex and size, individual growth, natural mortality, and the length-fecundity and length-weight relationships were compared. Most of the life history and population dynamics features of Emerita brasiliensis show clear geographical patterns: (1) a shift from continuous to seasonal reproductive and recruitment events from subtropical to temperate sandy beaches; (2) an increase in the individual size of the smallest ovigerous female and in the fecundity at size (length-fecundity relationship) from subtropical to temperate beaches; (3) a higher predominance of females towards temperate beaches; (4) an increase in male sizes towards subtropical beaches, following a direct relationship with mean water temperature of the surface zone; (5) a significant correlation between female growth parameters $\left(L_{\infty}=\right.$ inverse and $K$ and $\phi^{\prime}=$ direct) and surface water temperature; (6) an increase in the individual weight at size (length-weight relationship) from subtropical to temperate beaches, both for males and females; and (7) a linear decrease in life span and an asymptotic increase in natural mortality (both sexes) from temperate to subtropical beaches. The additional effect of morphodynamics at a regional scale was also detected, and in some cases masked or ameliorated clear latitudinal trends. Populations on dissipative beaches had a more extended reproductive season than in reflective beaches, as well as higher growth performance, fecundity and somatic weight at size. The decreasing occurrence of females in subtropical beaches might explain the unexpected but consistently increasing male crab sizes towards lower latitudes. This supports the hypothesis of asymmetric intraspecific competition between sexes, which may be considered a critical regulating process in sandy beach populations.
\end{abstract}

KEY WORDS: Mole crab $\cdot$ Emerita brasiliensis $\cdot$ Macroecology $\cdot$ Population dynamics $\cdot$ Sandy beaches $\cdot$ South America

Resale or republication not permitted without written consent of the publisher

\section{INTRODUCTION}

Large-scale studies in sandy beaches have been directed to mainly address latitudinal variations in aggre-

*E-mail: odefeo@mda.cinvestav.mx gated community descriptors of macroinfauna, such as species richness, diversity and abundance (Dexter 1992, Ricciardi \& Bourget 1999). Other large-scale quantitative analyses relate concurrent variations between these biological attributes and physical factors, such as grain size, beach slope and swash processes (e.g. McLachlan 
1990), but do not consider latitudinal trends. On the other hand, macroecology of population dynamics has been an historically neglected field in sandy beach ecology. There are no detailed studies of how species respond to large-scale environmental variations in demographic terms, i.e. whether individual growth, mortality, fecundity and other population dynamic features undergo latitudinal changes. A review of 15 species of clam from ocean beaches around the world showed that species with larger individual sizes and biomass dominate dissipative beaches of temperate zones, whereas generally smaller species are found on subtropical reflective beaches (McLachlan et al. 1996). Dugan et al. (1991, 1994) showed that water temperature affected some life history characteristics (e.g. female size at maturity, sizes of ovigerous females and size of the largest male) of Emerita analoga, and described geographic patterns of fecundity. However, a major impediment to detecting large-scale patterns in population dynamics of sandy beaches has been the dearth of medium/long-term data series directed to address variations in, e.g., growth and mortality rates with some confidence. In this context, most papers are based only on a snapshot, instantaneous samplings (1 sampling date per year) covering as many beaches as possible, which has been shown to be a weak approach when directed at elucidating variations in population dynamics and demography (Brazeiro \& Defeo 1996, Gómez \& Defeo 1999, Defeo et al. 2001).

The mole crab Emerita brasiliensis (Crustacea: Anomura: Hippidae) is commonly found in the intertidal of reflective and dissipative sandy beaches along the Atlantic coast of South America (see Fig. 1) from Rio de Janeiro (Brazil) to Montevideo (Uruguay) (Efford 1976, Tam et al. 1996). The common occurrence of this species in contrasting morphodynamic types along $2700 \mathrm{~km}$ of coastline (Veloso \& Cardoso 1999, Defeo et al. 2001) provides a unique opportunity to address geographical trends in population dynamics and demography and, at the same time, to assess the response of life history traits of an individual species to morphodynamics. This is of utmost importance, because some departures from clear large-scale patterns could be the response to local variations in physical (e.g. beach morphodynamics) and biological (e.g. competition) characteristics rather than to biogeographic effects.

In this paper, we determine latitudinal patterns in the population structure, dynamics and life history traits of the mole crab Emerita brasiliensis populations that inhabit exposed sandy beaches of South America. To this end, population structure by sex and size, fecundity, female size at maturity, reproductive and recruitment patterns, individual growth in size and weight, and natural mortality were compared. The concurrent potential roles of beach morphodynamics and latitude are also discussed.

\section{MATERIALS AND METHODS}

We analyzed information coming from 9 sandy beaches along the Atlantic coast of South America from Rio de Janeiro, Brazil $\left(22^{\circ} 57^{\prime} \mathrm{S}\right)$ to Arachania, Uruguay $\left(34^{\circ} 36^{\prime} \mathrm{S}\right)$ (Fig. 1, Table 1), covering the entire oceanic geographic distribution range of the species. A full characterization of the physical properties of Uruguayan beaches is detailed in Defeo et al. (1992b, 1997), Peluffo (1998) and Gómez \& Defeo (1999), and Brazilian beaches included in this study are described by Gianuca (1983, 1985), Santos (1994), Silveira (1997), Cardoso \& Veloso (1996), Veloso \& Cardoso (2001) and Cardoso et al. (in press). For the purpose of this paper, we only included information coming from studies with monthly samples taken at least for $1 \mathrm{yr}$ (Table 1). When available, data for each beach were partitioned into 12 mo intervals, and the results of life history traits derived from samplings in different years or even by identifying different cohorts were included as separate entities in the statistical analyses. Concerning Uruguayan beaches, the most common sampling design used was systematic, with 5 transects set up perpendicular to the shoreline and spaced $8 \mathrm{~m}$ apart. Sampling units (SUs) on each transect were done every $4 \mathrm{~m}$ with a sheet-metal cylinder, $27 \mathrm{~cm}$ in

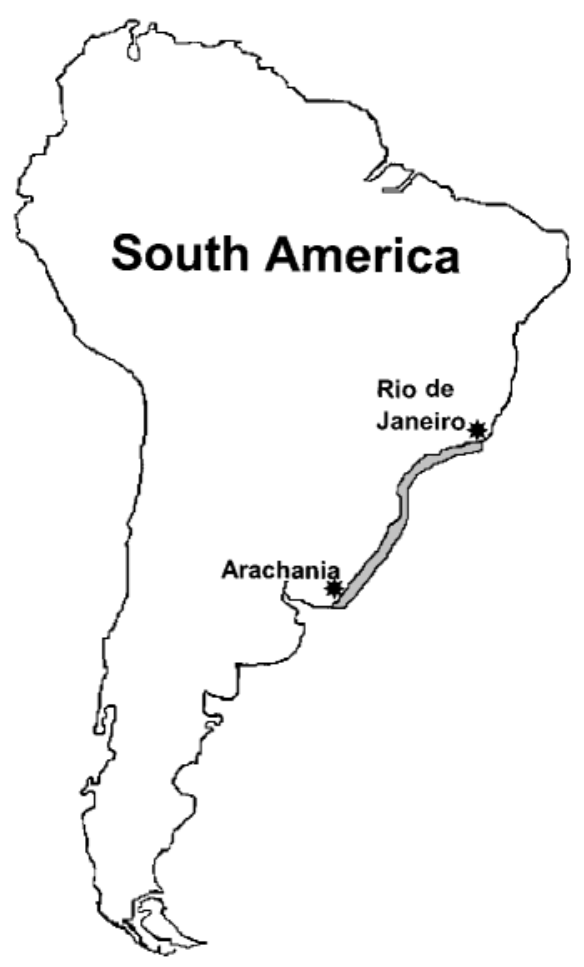

Fig. 1. Geographic distribution (shaded area) of the mole crab Emerita brasiliensis along the Atlantic coast of South America. The 2 extreme localities considered in this study, Arachania in the south and Rio de Janeiro in the north, are highlighted 
Table 1. Sampling details and physical attributes of the exposed sandy beaches Urca, Grumari, Restinga da Marambaia, Prainha, Cidreira and Cassino (Brazil) and Barra del Chuy, Polonio and Arachania (Uruguay). Cidreira: data from Silveira (1997); Cassino: data from Gianuca $(1983,1985)$; Polonio: data from Peluffo (1998). Data from the remaining beaches were directly collected by the authors. Abbreviations for each beach are subsequently used in the figures

\begin{tabular}{|c|c|c|c|c|c|c|c|c|c|}
\hline Beach features & $\begin{array}{l}\text { Urca } \\
\text { (U) }\end{array}$ & $\begin{array}{l}\text { Prainha } \\
\text { (P) }\end{array}$ & $\begin{array}{l}\text { Grumari } \\
\text { (G) }\end{array}$ & $\begin{array}{l}\text { Restinga da } \\
\text { Marambaia (R) }\end{array}$ & $\begin{array}{l}\text { Cidreira } \\
\text { (C) }\end{array}$ & $\begin{array}{c}\text { Cassino } \\
\text { (Ca) }\end{array}$ & $\begin{array}{l}\text { Barra del } \\
\text { Chuy (B) }\end{array}$ & $\begin{array}{l}\text { Polonio } \\
\text { (Po) }\end{array}$ & $\begin{array}{l}\text { Arachania } \\
\text { (A) }\end{array}$ \\
\hline Latitude South & $22^{\circ} 57^{\prime}$ & $23^{\circ} 02^{\prime}$ & $23^{\circ} 03^{\prime}$ & $23^{\circ} 03^{\prime}$ & $30^{\circ} 11^{\prime}$ & $32^{\circ} 14^{\prime}$ & $33^{\circ} 45^{\prime}$ & $34^{\circ} 23^{\prime}$ & $34^{\circ} 36^{\prime}$ \\
\hline Longitude West & $43^{\circ} 09^{\prime}$ & $43^{\circ} 29^{\prime}$ & $43^{\circ} 30^{\prime}$ & $43^{\circ} 36^{\prime}$ & $50^{\circ} 13^{\prime}$ & $52^{\circ} 10^{\prime}$ & $53^{\circ} 27^{\prime}$ & $53^{\circ} 46^{\prime}$ & $53^{\circ} 44^{\prime}$ \\
\hline Sampling duration (mo) & ) 30 & 24 & 26 & 26 & 12 & 18 & 22 & 13 & 22 \\
\hline Periodicity & Biweekly & Monthly & Monthly & Monthly & Biweekly & Monthly & Monthly & Monthly & Monthly \\
\hline Beach width (m) & 38 & $57^{1}$ & 53 & 76 & 50 & 60 & 68 & 96 & 40 \\
\hline Grain size (mm) & 0.36 & 0.43 & 0.52 & 0.25 & & 0.18 & 0.20 & 0.29 & 0.56 \\
\hline Sorting $(\mathrm{mm})$ & 0.69 & 0.36 & 0.28 & 0.25 & & & 0.70 & 0.41 & 0.30 \\
\hline Textural group & Coarse & Medium & Coarse & Fine & Fine & Fine & Fine & Medium & Coarse \\
\hline Slope $(\%)$ & 8.04 & 12.72 & 9.59 & 4.72 & & 3.00 & 3.53 & 2.65 & 7.80 \\
\hline Morphodynamics & Intermediate & Reflective & Reflective & Intermediate & Dissipative & Dissipative & Dissipative & Intermediate & e Reflective \\
\hline
\end{tabular}

diameter and $40 \mathrm{~cm}$ deep, from the base of the dunes to the seaward limit of the mole crab distribution, until at least 2 consecutive SUs yielded no mole crabs (Defeo et al. 2001). In Brazilian beaches, most collections were performed in 2 transects in the swash zone, which were divided into 10 strata parallel to the waterline, covering the entire across-shore distribution range of the species (Cardoso et al. in press). From each stratum, 4 replicates were taken using a $0.04 \mathrm{~m}^{2}$ metal sampler down to a depth of $25 \mathrm{~cm}$ (Veloso \& Cardoso 1999). The relative merits of each sampling design are discussed by Defeo \& Rueda (2002).

The mole crabs retained after sieving through a $0.5 \mathrm{~mm}$ mesh were fixed in $10 \%$ formalin and preserved in $70 \%$ ethanol, and, in the laboratory, measured to the nearest $0.5 \mathrm{~mm}$ carapace length (CL), i.e. from the tip of the rostrum to the distal scoop of the cephalothorax. Then, mole crabs were classified as megalops (non-adults) and adults. Megalops were those with an undeveloped ocular peduncle and presence of plumose pleopods (Veloso \& Cardoso 1999). Each adult was sexed and sorted into males, females without eggs and ovigerous females. Reproductive and recruitment patterns were inferred from, respectively, the frequency of occurrence of ovigerous females and megalops throughout a year.

Fecundity estimates were available for 4 sandy beaches: Fora (Brazil) and Barra del Chuy, Polonio and Arachania (Uruguay). To this end, ovigerous females were measured, weighed and washed in fresh tap water. Eggs were then removed from the pleopods and the total number of eggs per female was estimated as the ratio between egg mass volume and mean egg volume, following Diaz et al. (1983) and Lercari \& Defeo (1999). The carapace length-fecundity (CL-F) relationship was estimated by the power function $\mathrm{F}=a \times \mathrm{CL}^{b}$, where $a$ and $b$ are parameters. In this vein, data from Fora (Veloso \& Cardoso 1999) and Polonio (Peluffo
1998) beaches were reassessed and fitted to the above function. An ANCOVA was used to compare the CL-F relationships, and the Tukey Honest Significant Difference (HSD) test for unequal sample sizes were used for multiple comparisons (Zar 1999). Data were linearized in order to fulfil ANCOVA assumptions.

Monthly length frequency distributions discriminated by sex were used to estimate growth parameters of Emerita brasiliensis, by fitting the seasonalized von Bertalanffy growth function (VBGF: Gayanilo \& Pauly 1997) according to Gómez \& Defeo (1999) and Veloso \& Cardoso (1999). The growth index phi prime $\phi^{\prime}=2 \log _{10}\left(L_{\infty}\right)+\log _{10} K$ (where $L_{\infty}$ : asymptotic length, and $K$ : the curvature parameter of the VBGF) (Pauly \& Munro 1984, Defeo et al. 1992a) was used to measure growth performance. Longevity was estimated following Alagaraja (1984), using the CL containing $99 \%$ of the population $\left(\mathrm{CL}_{99 \%}\right.$ ) and the largest mode observed in the samples.

The carapace length-ash-free dry weight (CLAFDW) relationship was estimated separately by sex for Prainha, Barra del Chuy and Arachania, by a power function of the form $\mathrm{F}=a \times \mathrm{CL}^{b}$, where $a$ and $b$ are parameters. To this end, mole crabs were dried at 50 to $70^{\circ} \mathrm{C}$ for $24 \mathrm{~h}$ and weighted at least to the nearest $0.01 \mathrm{~g}$. Brazilian mole crabs were then ashed in a muffle furnace for $4 \mathrm{~h}$ at $600^{\circ} \mathrm{C}$ and then reweighted to obtain AFDW estimates, whereas individual dry weight of Uruguayan mole crabs were transformed to AFDW following Ricciardi \& Bourget (1998). An ANCOVA was used to compare the CL-AFDW relationship fitted for each sex between beaches, and the Tukey HSD test for unequal sample sizes was used for multiple comparisons. Data were linearized in order to fulfil ANCOVA assumptions.

The instantaneous coefficient of natural mortality $(M)$ was calculated for each population by length-converted catch curves (LCCC: Gayanilo \& Pauly 1997), 
using the corresponding length composition data discriminated by sex. For this purpose, we considered the classic negative exponential model as applied to length frequency data (Gayanilo \& Pauly 1997), which in its linearized form is given by: $\ln (\mathrm{n})=g-M \times t, \mathrm{n}$ being the number of mole crabs in cohorts 'sliced' by
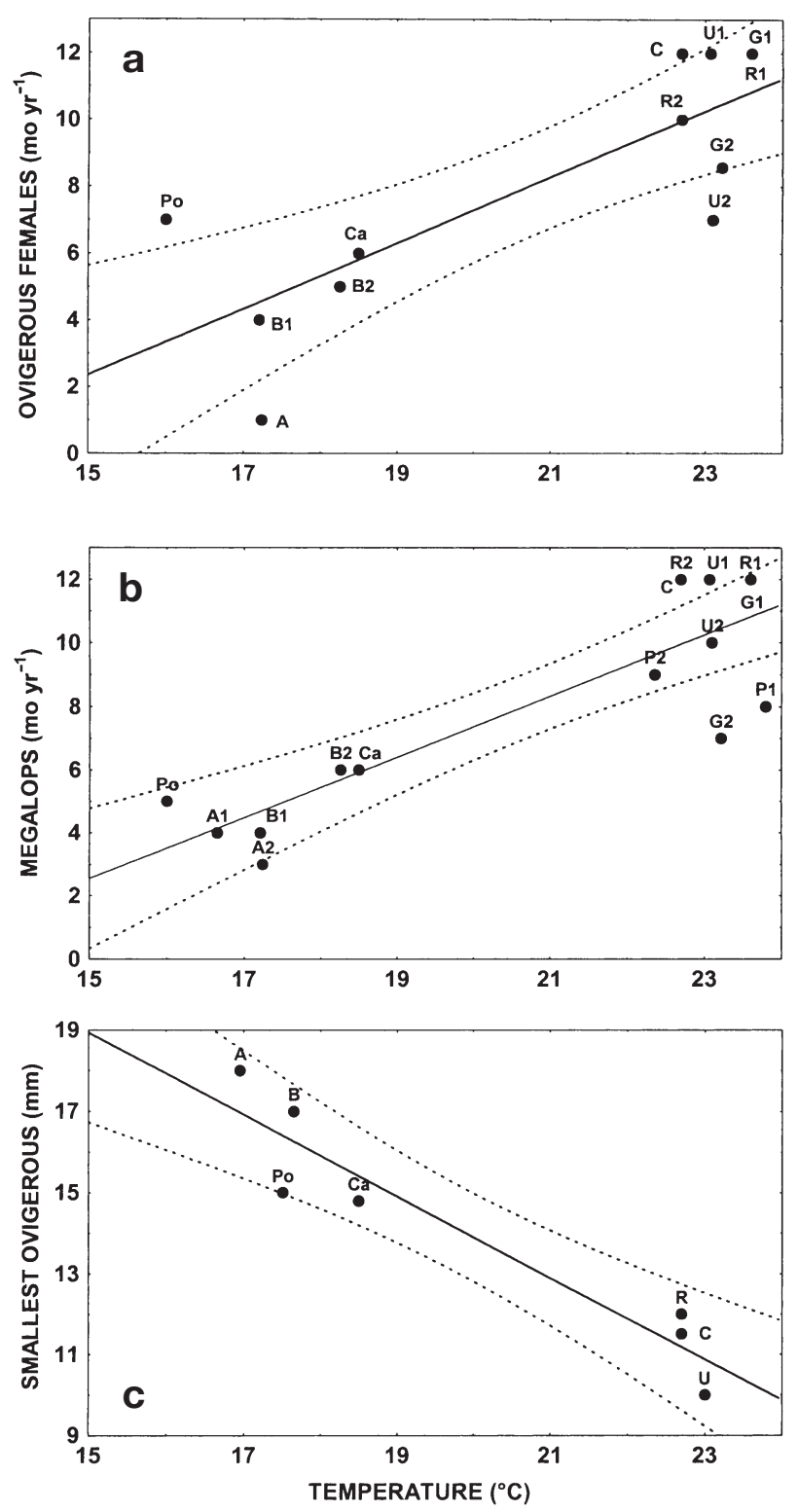

Fig. 2. Emerita brasiliensis. Bivariate correlation between surface water temperature and annual duration of (a) reproductive and (b) recruitment events and (c) smallest ovigerous females. The extent of the reproductive and recruitment seasons were quantified through the number of months that ovigerous females and megalops appeared in the samples. Statistical results and sample size are given in Table 2. Abbreviations beside each point refer to the corresponding beaches as in Table 1. Associated numbers refer to different years analyzed for the same beach means of successive growth curves, $g$ the regression intercept, $t$ the estimated age in each cohort, and $M$, with sign changed, the mortality estimate (Pauly et al. 1995).

Temperature was measured during sampling time at the surface zone of each beach. Additional information for Uruguayan and Brazilian beaches was available by the respective national meteorological services. Mean annual surface water temperature estimates were obtained for each locality as the average of individual estimates obtained in each sampling time. The relationship between population variables (e.g. growth, mortality, sex ratio) and water temperature (commonly used for detecting large-scale patterns in distribution and abundance of marine organisms) was modeled by linear or non-linear fitting procedures, particularly when the sample size was large enough to do so. This approach was considered more appropriate than multiple comparison procedures (Chew 1976).

\section{RESULTS}

\section{Reproductive biology}

Reproductive and recruitment patterns showed clear latitudinal gradients (Fig. 2). The number of months in a year that ovigerous females and megalops were recorded increased linearly with temperature $(\mathrm{n}=12$; $r=0.81 ; p<0.001$ for ovigerous females and $n=15$; $\mathrm{r}=0.86 ; \mathrm{p} \ll 0.001$ for megalops). Thus, reproductive and recruitment seasons tended to switch from markedly seasonal in temperate beaches (e.g. 1 to $5 \mathrm{mo} \mathrm{yr}^{-1}$ ) to continuous (10 to $12 \mathrm{mo} \mathrm{yr}^{-1}$ ) in subtropical ones. An additional effect of beach morphodynamics was detected: for roughly the same latitude, the dissipative Barra del Chuy and the intermediate Polonio had ovigerous females for 5 and $7 \mathrm{mo}$, respectively, whereas at the truly reflective Arachania they were recorded only in 1 month (Fig. 2a), indicating a much narrower reproductive season. The smallest ovigerous female significantly decreased with temperature $(\mathrm{r}=-0.95 ; \mathrm{p}<0.001)$, following a clear decreasing pattern from temperate to subtropical sandy beaches (Fig. 2c, Table 2). Indeed, the minimum size of an ovigerous female was 17 to $18 \mathrm{~mm}$ CL for temperate beaches, whereas those recorded for subtropical ones were almost $50 \%$ smaller (i.e. $10 \mathrm{~mm} \mathrm{CL}$ ). As in other figures, the gap in sites, with none in the range of temperatures intermediate between the 2 main groups, is due to the complete lack of information between the Brazilian beaches Restinga da Marambaia and Cidreira (Table 1).

The individual size of ovigerous females clearly increased from subtropical to temperate beaches. Thus, 
Table 2. Results of the bivariate correlation and associated statistics between population features of Emerita brasiliensis and mean surface water temperature $(T)$. The model with the best fit in each case is described. Significant correlations are highlighted in bold. Different sample size (n) in each bivariate correlation is due to the dissimilar amount of information: when available, data for each beach were partitioned to 12 mo intervals, and the results of life history traits derived from samplings in different years were included as separate entities in the statistical analyses

\begin{tabular}{|c|c|c|c|c|c|c|}
\hline Population features & Model & $a(\mathrm{SE})$ & $b(\mathrm{SE})$ & $\mathrm{r}$ & $\mathrm{n}$ & $\mathrm{p}$ \\
\hline Ovigerous females $\left(\mathrm{mo} \mathrm{yr}^{-1}\right)$ & $y=a+b T$ & $-12.46(4.76)$ & $0.99(0.23)$ & 0.81 & 12 & 0.0014 \\
\hline Megalops $\left(\mathrm{mo} \mathrm{yr}^{-1}\right)$ & $y=a+b T$ & $-11.87(0.30)$ & $0.96(0.16)$ & 0.86 & 15 & 0.0000 \\
\hline Smallest ovigerous (mm) & $y=a-b T$ & $34.04(3.07)$ & $-1.01(0.15)$ & -0.95 & 7 & 0.0012 \\
\hline ln [Sex ratio (female:male)] & $\ln y=a-b T$ & $3.31(1.19)$ & $-0.16(0.06)$ & -0.57 & 19 & 0.0106 \\
\hline Maximum length females (mm) & $y=a-b T$ & $33.74(7.54)$ & $-0.42(0.36)$ & -0.40 & 9 & 0.2814 \\
\hline Maximum length males (mm) & $y=a+b T$ & $6.03(2.51)$ & $0.43(0.12)$ & 0.80 & 9 & 0.0091 \\
\hline$L_{\infty}$ females $(\mathrm{mm})$ & $y=a-b T$ & $35.33(1.70)$ & $-0.47(0.08)$ & -0.86 & 15 & 0.0000 \\
\hline$L_{\infty}$ males $(\mathrm{mm})$ & $y=a+b T$ & $9.43(2.30)$ & $0.31(0.11)$ & 0.64 & 14 & 0.0137 \\
\hline$K$ females $\left(\mathrm{yr}^{-1}\right)$ & $y=a+b T$ & $-0.85(0.48)$ & $0.30(0.02)$ & 0.85 & 15 & 0.0001 \\
\hline$K$ males $\left(\mathrm{yr}^{-1}\right)$ & $y=a-b T$ & $2.02(0.80)$ & $-0.01(0.04)$ & -0.09 & 15 & 0.7576 \\
\hline Phi prime $\phi^{\prime}$ females & $y=a+b T$ & $2.58(0.15)$ & $0.02(0.01)$ & 0.68 & 14 & 0.0080 \\
\hline Phi prime $\phi^{\prime}$ males & $y=a+b T$ & $2.46(0.18)$ & $0.01(0.01)$ & 0.25 & 15 & 0.3641 \\
\hline Life span females (mo) & $y=a-b T$ & $25.37(5.68)$ & $-0.75(0.26)$ & -0.63 & 15 & 0.0127 \\
\hline Life span males (mo) & $y=a-b T$ & $14.95(2.35)$ & $-0.27(0.11)$ & -0.57 & 15 & 0.0258 \\
\hline
\end{tabular}

the $\mathrm{CL}($ mean $\pm \mathrm{SD}$ ) of ovigerous females was $17.32 \pm$ $3.55 \mathrm{~mm}$ for Urca (Brazil, 22 ${ }^{\circ} 57^{\prime} \mathrm{S}$ ) and $21.23 \pm 1.72 \mathrm{~mm}$ for Barra del Chuy (Uruguay, $33^{\circ} 45^{\prime} \mathrm{S}$ ), with a mean egg production of, respectively, $3704 \pm 2538$ eggs female $^{-1}$ and $9099 \pm 3543$ eggs female f $^{-1}$, i.e. almost 2.5 times higher. The linearized CL-F relationship showed significant differences between the 4 beaches analyzed (ANCOVA $F_{3,133}=4.36 ; \mathrm{p}<0.006$ ) (Table 3 ). Each regression significantly differed with the other ones (Tukey's HSD: $p \ll 0.01$ ). Our analysis also suggests a clear effect of morphodynamics: comparison between reflective (Arachania) and dissipative (Polonio and Barra del Chuy) Uruguayan sandy beaches showed that the latter ones have significantly higher fecundity at size than the reflective one (Table 3).

Table 3. Emerita brasiliensis. Parameters of the linearized fecundity function fitted for Urca, Barra del Chuy, Polonio and Arachania populations. ANCOVA results (log-transformed data) are also shown, including tests of homogeneity of slopes and differences in fecundity at length (main effect) between beaches. ' $a$ ' and ' $b$ ' represent, respectively, the intercept and slope of the linearized fecundity function

\begin{tabular}{|c|c|c|c|c|c|c|c|}
\hline \multirow{2}{*}{ Parameter } & \multicolumn{2}{|c|}{$-\ln a$} & \multicolumn{2}{|c|}{$b$} & \multirow[t]{2}{*}{$\mathrm{r}^{2}$} & \multirow[t]{2}{*}{$\mathrm{n}$} & \multirow[t]{2}{*}{$\mathrm{p}$} \\
\hline & Mean (SE) & $\mathrm{p}$ & Mean (SE) & $\mathrm{p}$ & & & \\
\hline Urca & $-1.77(0.46)$ & 0.0009 & $3.45(0.23)$ & 0.0000 & 0.96 & 22 & 0.0000 \\
\hline Barra del Chuy & $-3.33(1.75)$ & 0.0655 & $4.05(0.57)$ & 0.0000 & 0.58 & 38 & 0.0000 \\
\hline Polonio & $-3.97(1.36)$ & 0.0077 & $4.20(0.46)$ & 0.0000 & 0.79 & 24 & 0.0000 \\
\hline Arachania & $0.27(2.49)$ & 0.9146 & $2.82(0.82)$ & 0.0012 & 0.18 & 54 & 0.0012 \\
\hline \multicolumn{8}{|l|}{ ANCOVA } \\
\hline \multicolumn{8}{|c|}{ Homogeneity of slopes: $F_{3,130}=1.15 ; \mathrm{p}=0.3304$} \\
\hline \multicolumn{8}{|c|}{ Main effect (fecundity-at-size between beaches): $F_{3,133}=4.36 ; \mathrm{p}=0.0058$} \\
\hline
\end{tabular}

\section{Growth and population structure}

The inverse relationship between the largest mole crab females and temperature was not statistically significant, but male mole crabs had the largest sizes in subtropical sandy beaches, meaning a direct and significant relationship between CL and mean water temperature $(r=0.80 ; p<0.01$ : Fig. 3a). Conversely, males were largest in subtropical beaches when the predominance of females was significantly lower (Fig. 3b), and thus the female:male ratio significantly decreased with water temperature $(r=-0.60 ; p<0.01)$ according to a monotonically decreasing exponential function of the form:

Sex ratio $=3.58 \mathrm{e}^{-0.17 T}$

where the sex ratio is expressed as a proportion of females and $T$ is water temperature.

Growth parameters of the VBGF $L_{\infty}$ and $K$ were inversely and significantly (females: $\mathrm{r}=-0.66$; $\mathrm{p}<0.008$ : Table 2) correlated or marginally significantly (males: $r=-0.50 ; p=0.07$ ) correlated with each other. Some geographic trends emerged from the 14 growth estimates compiled from the literature (Fig. 4): (1) The temperate, reflective Arachania beach was rather isolated, with comparatively high $L_{\infty}$ and low $K$ values, but followed closely the regression lines fitted for all populations and sexes; (2) mole crabs (both sexes) from the other temperate beach, 

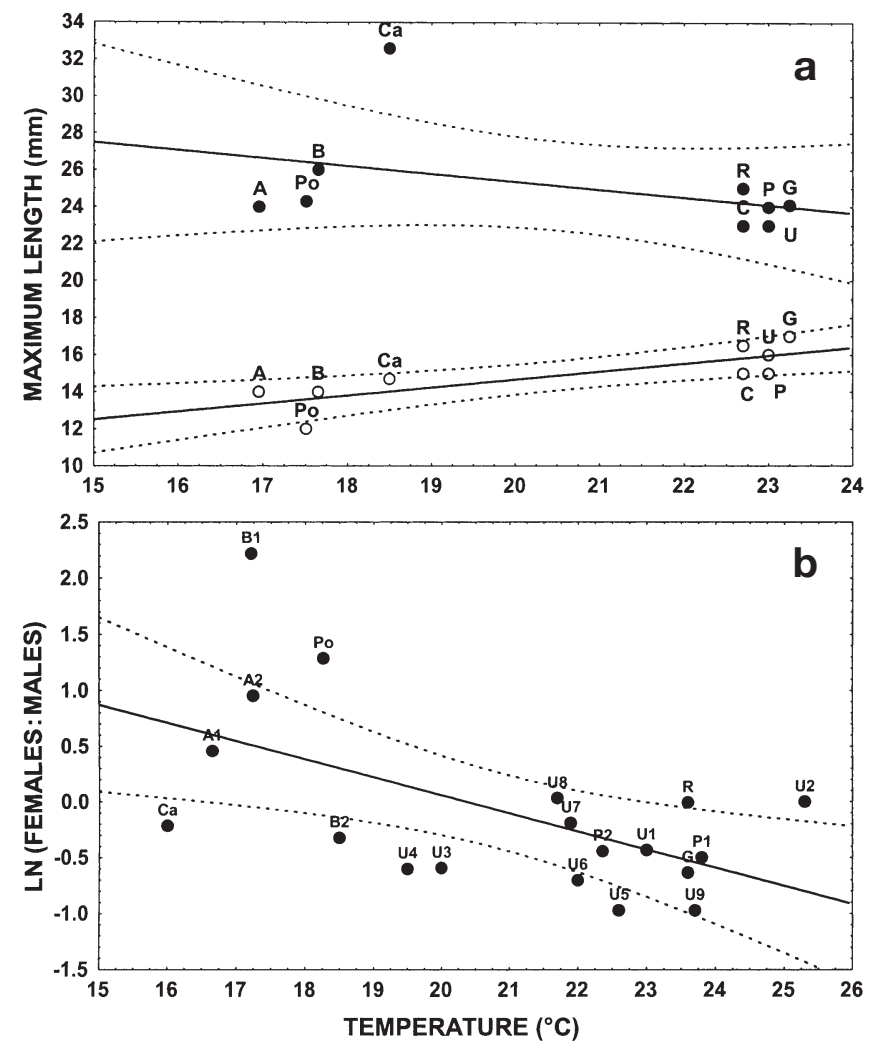

Fig. 3. Emerita brasiliensis. Bivariate correlation between surface zone water temperature and (a) largest individual length of $(\bullet)$ females and (o) males, and (b) the sex ratio female:male (Eq. 1). Statistical results and sample size are given in Table 2. Abbreviations beside each point refer to the corresponding beaches as in Table 1. Associated numbers in (b) refer to different cohorts analyzed for the same beach

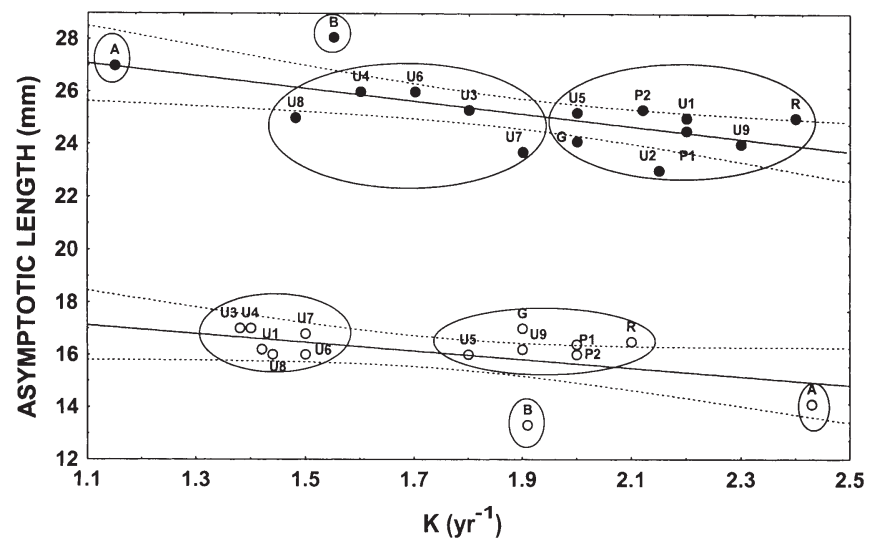

Fig. 4. Emerita brasiliensis. Bivariate correlation $( \pm 95 \%$ confidence intervals) between growth parameters $K$ and $L_{\infty}$ for (•) females and (o) males. Abbreviations beside each point refer to the corresponding beaches as in Table 1. Associated numbers refer to different cohorts analyzed for the same beach. Different groups are encircled (see text for details) the dissipative Barra del Chuy, had combinations of growth parameters located far away from the 95\% confidence intervals of both regressions, meaning an unexpectedly high $L_{\infty}$ value for the estimated $K$ (females) and vice versa for males; and (3) 2 distinct non-overlapping clusters of combinations of $L_{\infty}$ and $K$ values were distinguished for subtropical populations: one comprising a combination of estimates from Urca cohorts with lower $K$ values and the other group with mainly clustered estimates from Prainha, R. da Marambaia and Grumari. Differences between groups could also be explained by the local morphodynamic effects: Urca is a semi-exposed beach, whereas the other 3 are truly exposed beaches (Cardoso \& Veloso 1999).

Most sex-specific variations in $L_{\infty}$ and $K$ were correlated with temperature (Fig. 5). Mole crab females showed clear latitudinal gradients in both parameters, with $L_{\infty}$ inversely $(\mathrm{r}=-0.86 ; \mathrm{p}<0.00004)$ and $K$ positively $(r=0.85 ; \mathrm{p}<0.00006)$ correlated with surface water temperature (Fig. 5a). Some $5 \mathrm{~mm}$ difference in $L_{\infty}$ were found between the temperate dissipative Barra del Chuy (28 mm CL) and the subtropical reflective Urca (23 mm CL), suggesting an unambiguous trend for mole crab females to attain larger sizes with lower growth rates at temperate sandy beaches. In the case of males, $L_{\infty}$ was directly correlated with temperature $(\mathrm{r}=0.64 ; \mathrm{p}<0.01 ; 1$ outlier omitted $)$, thus following the reverse trend as in females. $L_{\infty}$ attained asymptotic sizes up to 1.3 times higher in the northern end of Emerita brasiliensis distribution than in the southern end (Fig. 5b).

Growth performance of mole crab females increased linearly with temperature according to the model $\phi^{\prime}=2.58+0.02 T(\mathrm{r}=0.68 ; \mathrm{n}=14 ; \mathrm{p}<0.008$ : Table 2$)$. The data point corresponding to Barra del Chuy emerged as an outlier according to single extreme observation analysis. The omission of this point considerably changed the slope of the regression line and shifted the correlation coefficient from non-significant to highly significant. As mentioned above for Fig. 5, the effect of morphodynamics and associated ecosystem characteristics could be invoked to explain this trend. Barra del Chuy is a dissipative beach categorized as a semi-closed ecosystem with high primary productivity provided by huge amount of surface diatoms living in the surface zone. This could explain the extremely high value of $\phi^{\prime}$ (3.29) provided by high values of $L_{\infty}$ and $K$ when compared with analogous populations at higher latitudes (e.g. Arachania: $\phi^{\prime}=2.92$ ). This indicates that the female mole crabs at Barra del Chuy outperform other populations primarily by attaining larger sizes through unexpectedly high growth rates. Conversely, male mole crabs did not exhibit any significant largescale trend in growth performance, even though $\phi^{\prime}$ also tended to increase with temperature (Table 2). 

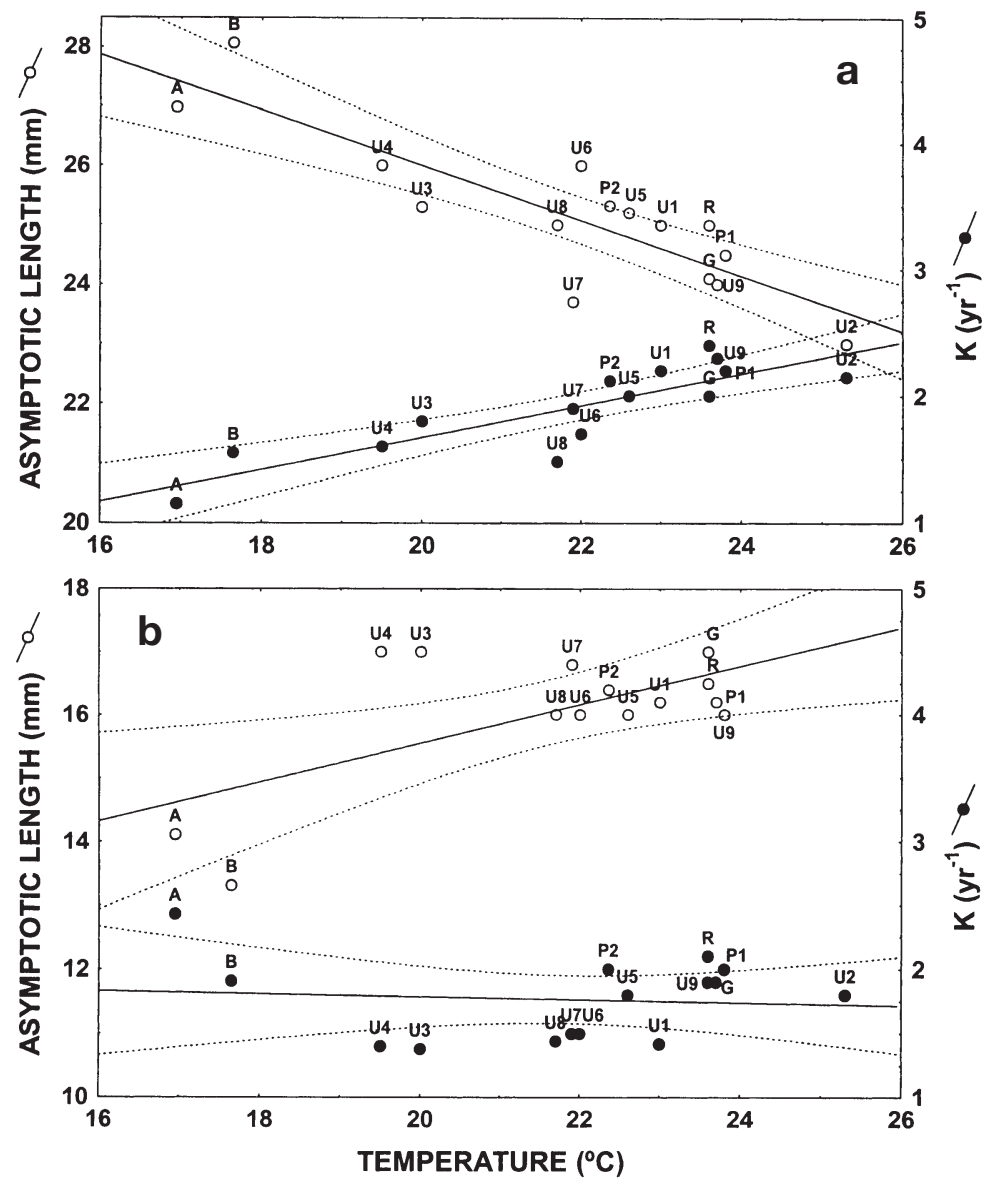

Fig. 5. Emerita brasiliensis. Bivariate correlation $( \pm 95 \%$ confidence intervals) between water temperature of the surface zone and growth parameter estimates (•) $K$ and (o) $L_{\infty}$ for (a) females and (b) males. Statistical results and sample size are given in Table 2. Abbreviations beside each point refer to the corresponding beaches as in Table 1. Associated numbers refer to different cohorts analyzed for the same beach
Life span determined by population structure features showed an inverse and significant relationship with temperature, both for females ( $\mathrm{r}=$ $0.63 ; \mathrm{p}<0.013)$ and males $(\mathrm{r}=0.57$; $\mathrm{p}<0.026)$. This implies a life span 2.6 times lower for females inhabiting subtropical beaches (Urca: $6.1 \mathrm{mo}$ ) when compared to their temperate counterparts (Arachania: $16 \mathrm{mo}$ ); for males the differences between minimum (Urca: $7.1 \mathrm{mo}$ ) and maximum (Arachania-Barra del Chuy: $11 \mathrm{mo}$ ) life span estimates reached ca. $35 \%$ (Fig. 6, Table 2).

The AFDW at size of mole crab females increased at higher latitudes (Fig. 7a), and the corresponding linearized CL-AFDW relationship differed significantly between beaches (homogeneity of slopes: $F_{2,1222}=1.70 ; \mathrm{p}=0.1825 ;$ main effect of weight-at-size between beaches: $F_{2,1224}=49.64$; $\mathrm{p} \ll 0.001)$. Multiple a posteriori comparisons showed the concurrent effects of latitude and morphodynamics: (1) all CL-AFDW relationships differed between each other $(p<0.01)$ with individual AFDW being significantly higher at Barra del Chuy; and (2) comparison between reflective (Arachania) and dissipative (Barra del Chuy) Uruguayan sandy beaches showed a significantly higher AFDW at size for the latter (Tukey's HSD test: $\mathrm{p} \ll 0.01)$. Male weight-at-size also differed between beaches (ANCOVA: homogeneity of slopes: $F_{2,811}=1.29 ; \mathrm{p}=0.2757$; main effect: $F_{2,813}=$ 16.70; p $<0.001$ : Fig. 7b). Multiple a posteriori comparisons showed that: (1) the CL-AFDW relationships at higher latitudes were significantly higher than at subtropical Prainha (Tukey's HSD test: $\mathrm{p}<0.01$ ); and (2) Uruguayan CL-AFDW relationships did not differ from each other (Tukey's HSD test: $\mathrm{p}>0.05)$.
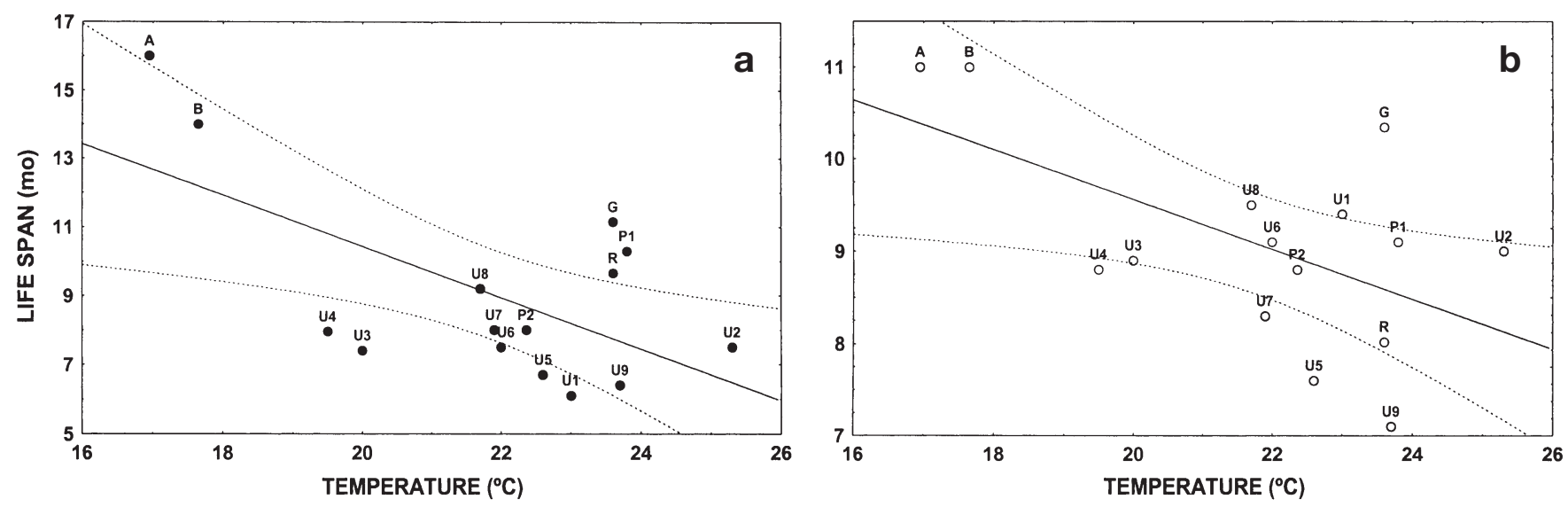

Fig. 6. Emerita brasiliensis. Bivariate correlation ( $\pm 95 \%$ confidence intervals) between water temperature of the surface zone and life span of (a) females and (b) males. Statistical results and sample size are given in Table 2. Abbreviations beside each point refer to the corresponding beaches as in Table 1. Associated numbers refer to different cohorts analyzed for the same beach 

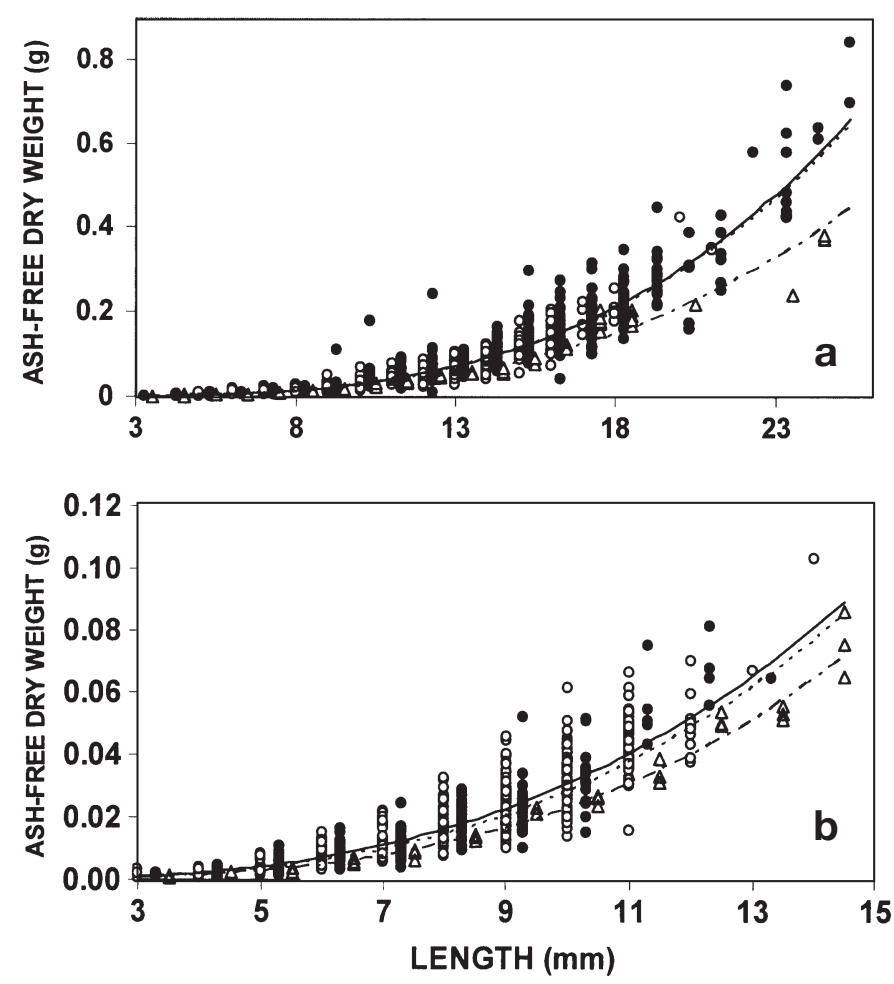

Fig. 7. Emerita brasiliensis. Geographical variation in the individual length-weight relationship for Prainha $(--\Delta--$, latitude $\left.23^{\circ} 02^{\prime} \mathrm{S}\right)$, Barra del Chuy ( $\multimap$, latitude $\left.33^{\circ} 45^{\prime} \mathrm{S}\right)$ and Arachania (- - - - , latitude $34^{\circ} 36^{\prime} \mathrm{S}$ ): (a) females and (b) males

\section{Mortality}

Large-scale variations in natural mortality $(M)$ for both sexes increased asymptotically with temperature according to a non-linear model of the form (Fig. 8):

$$
M=M_{\infty}\left[1-\mathrm{e}^{-\alpha\left(T-T_{\min }\right)}\right]
$$

where $M$ is the instantaneous natural mortality coefficient, $M_{\infty}$ is the asymptotic mortality, $\alpha$ is a curvature parameter that measures how fast the species approaches $M_{\infty}$ and $T_{\min }$ is the theoretical threshold temperature value below which the species does not occur in nature. The global model and its parameters were statistically significant $(p<0.01)$ even when 3 outliers ( 2 for males and 1 for females) were included for model fitting (see encircled data in Fig. 8). $M_{\infty}$ was $11.24 \mathrm{yr}^{-1}$ for females and $9.79 \mathrm{yr}^{-1}$ for males. This could be explained by the weighted effect of extremely high female mortalities at subtropical beaches, that were on average 2.55 (males) and 2.79 (females) times higher than in temperate ones. Parameter $\alpha$ was 0.73 for females and 0.75 for males, indicating a similar curvature of the function, whereas $T_{\min }$ was $16.49^{\circ} \mathrm{C}$ for females and $16.52^{\circ} \mathrm{C}$ for males. These values are con- sistent with the mean water temperature of species occurrence in its southern distribution end (Fig. 8).

\section{DISCUSSION}

The large-scale study of the mole crab Emerita brasiliensis showed strong latitudinal patterns in life history and population dynamics throughout its entire distribution range. Results obtained from applying a data base consisting of studies carried out on at least 12 mo consecutive sampling dates provided strong support to the latitudinal gradient hypothesis (LGH): subtropical beaches exhibited higher growth (females) and mortality rates and shorter life spans (both sexes) than temperate beaches. The size of the smallest ovigerous female and fecundity and weight at size decreased towards lower latitudes, where continuous reproduction was evident, whereas temperate populations presented marked seasonality in reproductive and recruitment patterns. These latitudinal trends could be related to variations in temperature, which constitutes an 'aggregate variable' that is correlated with different simultaneous effects in the nearshoresurface zone environment (e.g. food availability). Despite this, a direct and significant relationship between the largest asymptotic carapace sizes of male mole crabs and water temperature was found, thus following the reverse pattern predicted by the LGH. Possible explanations of these general results are discussed below.

The duration of the breeding and recruitment events varied from markedly seasonal in temperate beaches (e.g. 1 to $5 \mathrm{mo} \mathrm{yr}^{-1}$ ) to continuous (10 to $12 \mathrm{mo} \mathrm{yr}^{-1}$ ) in

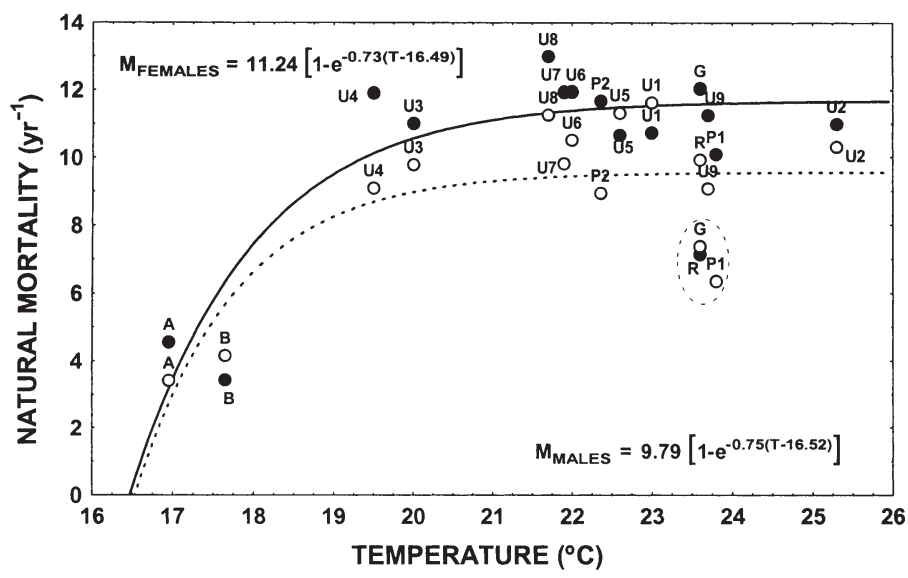

Fig. 8. Emerita brasiliensis. Asymptotic model (Eq. 2) relating mean surface water temperature and natural mortality for $(\bullet-)$ females and (--O--) males. Outliers (encircled) were nevertheless used for model fitting. Abbreviations beside each point refer to the corresponding beaches as in Table 1. Associated numbers refer to different cohorts analyzed for the same beach 
subtropical ones. The length of both seasons seems to be determined by an increase in temperature, as suggested for most marine invertebrates (Kinne 1970). The continuous reproductive activity of subtropical female mole crabs could counteract the significantly smaller ovigerous sizes and size-specific fecundity (see also Veloso et al. 1995). These trends were accompanied by higher mortality rates at lower latitudes, suggesting that eggs produced by smaller females could certainly affect total reproductive output (Wenner et al. 1993, Lercari \& Defeo 1999). Female mole crabs at high latitudes would achieve larger sizes and weights by delaying maturity and thus they should be able to allocate more resources to reproduction and somatic growth than in subtropical beaches. It is also expected that size at maturity increases with lower temperatures, as demonstrated by Dugan et al. (1994) for Emerita analoga, but this hypothesis requires further testing.

As subtropical beaches are reflective or intermediate, a concurrent effect of morphodynamics and latitude (i.e. temperature) may be a possibility. Dissipative beaches have been defined as self-sustaining or semiclosed ecosystems (sensu McLachlan 1980), in which food availability is provided in high amounts by the beach itself and by a surface zone extremely rich in surface phytoplankton (Lewin \& Schaefer 1983, Campbell 1996). Hence, for suspension feeders, these beaches are more suitable habitats for feeding than reflective beaches (McLachlan 1983, Defeo \& Scarabino 1990) than subsidized reflective systems, with reduced food availability. Suitable conditions for diatom accumulations are long dissipative beaches of moderate to high energy, rip current activity and an associated dune system providing nutrients by groundwater flow (Campbell 1996). These conditions are primarily met in the southern dissipative sandy beaches Barra del Chuy (Defeo \& Scarabino 1990), Cassino (Gianuca 1983) and Cidreira, suggesting a latitudinal gradient in food availability. Dugan et al. (1994) also showed that geographic variation in 4 life history characteristics of Emerita analoga females was negatively correlated with surface zone water temperature and positively correlated with food availability (chlorophyll a) at dissipative systems (see also Wenner et al. 1987, 1993), giving support to our results.

The local effect of morphodynamics ameliorated latitudinal trends: for roughly the same latitude (i.e. for a given water temperature), females at the dissipative beach Barra del Chuy had a more extended reproductive season than in the reflective Arachania, as well as significantly higher growth performance $\left(\phi^{\prime}\right)$, fecundity and somatic weight at size, together with lower mortality rates (Defeo et al. 2001). These higher indicators for the dissipative beach suggest more efficiency in the rates of conversion of food into somatic tissue and could be attributed to higher food availability. Higher mortality rates at the reflective beach could explain the absence of ovigerous females almost throughout the study period (see Fig. 2 and Defeo et al. 2001). Dugan et al. (1994) also reported the largest sizes of ovigerous Emerita analoga sand crabs at dissipative beaches with major amount of food availability. The high success of female mole crabs in dissipative systems gives support to the swash exclusion hypothesis (SEH) (see McLachlan 1990, Defeo et al. 2001 for details). Gómez \& Defeo (1999) found higher individual weight, fecundity and average size at maturity for the sandhopper Pseudorchestoidea brasiliensis at a dissipative beach, concluding that the major reproductive success in these beaches remains valid for species living outside the swash climate.

Prediction of the Bergmann's rule holds only for females. Bergmann's rule, originally formulated for mammals but now extended to other groups, states that organisms living in colder areas are larger than their counterparts in subtropical areas (Manly 1998). In agreement with this rule, individual sizes and growth intensity $\left(\phi^{\prime}\right)$ of female mole crabs increased towards temperate beaches. However, male mole crabs showed the reverse pattern, i.e. largest sizes significantly increased from south to north. This goes against the well-documented inverse correlation between temperature and body size (Kinne 1970) and suggests that optimal individual sizes and growth rates of males are likely to be affected in a different way by temperature or even by other factors. Concurrent changes in sex ratio and male sizes could explain this large-scale pattern. A significant inverse linear correlation between sex ratio (female:male, Fig. 3b) along with (1) largest size $(\mathrm{r}=-0.71 ; \mathrm{p}<0.03)$, (2) asymptotic length $(\mathrm{r}=$ $-0.72 ; \mathrm{p}<0.01)$, and (3) life span $(\mathrm{r}=-0.63 ; \mathrm{p}<0.01)$ of males were detected. This suggests that the increasing predominance of females at temperate beaches could inhibit sizes and life span of males. Shifting sex ratios and a resulting shorter life expectancy for males has also been documented by Diaz (1980) in a local study for Emerita talpoida at North Carolina.

The above-mentioned patterns can be interpreted by citing a variety of biological phenomena including compensation (density dependence). Lercari \& Defeo (1999) recently postulated this as a mesoscale hypothesis, by successfully modeling spatial density-dependent growth in male mole crabs Emerita brasiliensis at the $22 \mathrm{~km}$ long Barra del Chuy beach, through an inverse correlation between male sizes and total abundance of E. brasiliensis. Lercari (2000) also showed a significant inverse correlation between female abundance and male sizes. A greater filtering capacity and individual growth rates in females might constrain food availability and accessibility to smaller males, considered as subordinate intraspecific competitors for 
food (Lercari \& Defeo 1999, Defeo et al. 2001). At a local scale, Dugan \& Hubbard (1996) also found that the largest sizes of males and ovigerous females of E. analoga were inversely correlated with total abundance, suggesting potential intraspecific interactions.

In males, the response to morphodynamics did not follow SEH predictions. At a given temperature, male mole crabs attained significantly higher growth and lower mortality rates at Arachania (reflective) than at the dissipative Barra del Chuy (see Defeo et al. 2001). In the latter, low growth rates could be explained by the density-dependent mechanism detailed above, whereas high mortality rates are explained by much higher rates of size-dependent predation by vertebrates and invertebrates at dissipative beaches. Postdispersal density dependence could involve various forms of inhibition of male growth by local female residents, notably depletion patterns of local food resources. Indeed, the effect of actively pumping water by suspension feeders depleting suspended foods and depressing individual growth rates has been documented in other soft-bottom habitats (Peterson 1982, Peterson \& Black 1987). This 'density induced negative feedback' (Berryman 1997) resulting from asymmetric intraspecific competition between sexes or population components (i.e. adults vs recruits) is now considered a critical regulating process in sandy beach populations (Defeo \& de Alava 1995, Defeo 1996, 1998). A better understanding of the mechanisms that underlies intraspecific interactions between sexes, as well as developmental relationships between temperature and body size, may help us to understand both large- and mesoscale responses in these dynamic environments.

In summary, 2 processes operating at markedly different spatial scales could explain the above patterns in female mole crabs: (1) a macroscale process caused by the latitudinal influence of temperature and cycles of production; and (2) a major efficiency of food conversion in dissipative temperate systems. Opposite patterns observed for males suggest that densitydependent mechanisms acting at small operational spatial scales control growth rates as a function of predominance and larger sizes of females. In the case of males, both macro- and mesoscale trends in life history traits did not follow the prevailing hypotheses formulated at these different spatial scales (LGH and SEH, respectively). This provides additional support to the perception that sandy beach populations seem to be controlled by the interaction between densityindependent and density-dependent factors operating together (Defeo \& de Alava 1995, Defeo et al. 1997, Lima et al. 2000). The presence of a strong interaction in 1 region does not guarantee its existence at all sites or times (Dethier \& Duggins 1988). Thus, our analysis of macroscale and mesoscale patterns could be com- bined with information on physiology, genetics (Soares et al. 1999) and field/laboratory experimentation (Defeo et al. 1997) to go beyond correlational patterns and thereby address generalities about the determinants of dynamics and demography in sandy beach populations. Because of the scale dependence, studies in exposed sandy beach macrofauna should be designed to incorporate a number of hierarchical scales to better understand its distribution patterns.

Acknowledgements. This paper is part of the $\mathrm{PhD}$ thesis of R.S.C. at PEDECIBA Uruguay. We wish to express our gratitude to our students, colleagues and friends that helped us during the last 10 yr. Dr. John Caddy, Dr. Charles Peterson and 4 anonymous referees gave us useful suggestions. We are especially grateful to Helena, Anita and Dr. Simba for support. O.D. acknowledges support from CONICYT, CSIC and PEDECIBA Uruguay. R.S.C. acknowledges financial support from CNPq and FAPERJ.

\section{LITERATURE CITED}

Alagaraja K (1984) Simple methods for estimation of parameters for assessing exploited fish stocks. Indian J Fish 31: $177-208$

Berryman AA (1997) On the principles of population dynamics and theoretical models. Am Entomol 43:147-151

Brazeiro A, Defeo O (1996) Macroinfauna zonation in microtidal sandy beaches: is it possible to identify patterns in such variable environments? Estuar Coast Shelf Sci 42: 523-536

Campbell EE (1996) The global distribution of surface diatom accumulations. Rev Chil Hist Nat 69:495-501

Cardoso RS, Veloso VG (1996) Population biology and secondary production of the sandhopper Pseudorchestoidea brasiliensis (Amphipoda: Talitridae) at Prainha beach, Brazil. Mar Ecol Prog Ser 142:111-119

Cardoso RS, Veloso VG, Caetano CHS (in press) Life history of Emerita brasiliensis (Decapoda: Hippidae) on two beaches with different morphodynamic characteristics. J Coast Res (Special Issue 35)

Chew V (1976) Comparing treatment means: a compendium. Hortic Sci 11:348-356

Defeo O (1996) Experimental management of an exploited sandy beach bivalve population. Rev Chil Hist Nat 69: 605-614

Defeo O (1998) Testing hypotheses on recruitment, growth and mortality in exploited bivalves: an experimental perspective. Can Spec Publ Fish Aquat Sci 125:257-264

Defeo O, de Alava A (1995) Effects of human activities on long-term trends in sandy beach populations: the wedge clam Donax hanleyanus in Uruguay. Mar Ecol Prog Ser 123:73-82

Defeo O, Rueda M (2002) Spatial structure, sampling design and abundance estimates in sandy beach macroinfauna: some warnings and new perspectives. Mar Biol 140: $1215-1225$

Defeo O, Scarabino V (1990) Ecological significance of a possible deposit-feeding strategy in Mesodesma mactroides (Deshayes, 1854) (Mollusca: Pelecypoda). Atlántica (Brazil) 12:55-65

Defeo O, Arreguín-Sánchez F, Sánchez J (1992a) Growth study of the yellow clam Mesodesma mactroides: a com- 
parative analysis of three length-based methods. Sci Mar $56: 53-59$

Defeo O, Jaramillo E, Lyonnet A (1992b) Community structure and intertidal zonation of the macroinfauna in the Atlantic coast of Uruguay. J Coast Res 8:830-839

Defeo O, Brazeiro A, de Alava A, Riestra G (1997) Is sandy beach macroinfauna only physically controlled? Role of substrate and competition in isopods. Estuar Coast Shelf Sci 45:453-462

Defeo O, Gómez J, Lercari D (2001) Testing the swash exclusion hypothesis in sandy beach populations: the mole crab Emerita brasiliensis in Uruguay. Mar Ecol Prog Ser 212: 159-170

Dethier MN, Duggins DO (1988) Variation in strong interactions in the intertidal zone along a geographical gradient: a Washington-Alaska comparison. Mar Ecol Prog Ser 50: 97-105

Dexter DM (1992) Sandy beach community structure: the role of exposure and latitude. J Biogeogr 19:59-66

Díaz H (1980) The mole crab Emerita talpoida (Say): a case of changing life history pattern. Ecol Monogr 50:437-456

Díaz H, Conde JE, Bevilacqua M (1983) A volumetric method for estimating fecundity in Decapoda. Mar Ecol Prog Ser 10:203-206

Dugan JE, Hubbard DM (1996) Local variation in populations of the sand crab Emerita analoga on sandy beaches in southern California. Rev Chil Hist Nat 69:579-588

Dugan JE, Wenner AM, Hubbard DM (1991) Geographic variation in the reproductive biology of the sand crab, Emerita analoga (Stimpson) on the California coast. J Exp Mar Biol Ecol 150:63-81

Dugan JE, Hubbard DM, Wenner AM (1994) Geographic variation in life history of the sand crab, Emerita analoga (Stimpson) on the California coast: relationships to environmental variables. J Exp Mar Biol Ecol 181:255-278

Efford IE (1976) Distribution of the sand crab in the genus Emerita (Decapoda, Hippidae). Crustaceana 30:169-183

Gayanilo FC Jr, Pauly D (1997) FAO-ICLARM stock assessment tools: reference manual. FAO computerized information series (Fisheries), No. 8. FAO, Rome, p 262

Gianuca NM (1983) A preliminary account of the ecology of sandy beaches in southern Brazil. In: McLachlan A, Erasmus T (eds) Sandy beaches as ecosystems. W Junk, The Hague, p 413-419

Gianuca NM (1985) The ecology of sandy beach in southern Brazil. PhD thesis, University of Southampton

Gómez J, Defeo O (1999) Life history of the sandhopper Pseudorchestoidea brasiliensis (Amphipoda) in sandy beaches with contrasting morphodynamics. Mar Ecol Prog Ser 182:209-220

Kinne O (1970) Temperature: animals-invertebrates. In: Kinne O (ed) Marine ecology, Vol 1. Environmental factors. Wiley-Interscience, New York, p 407-514

Lercari D (2000) Efectos de la descarga de agua dulce en poblaciones de playas arenosas: el 'tatucito' Emerita brasiliensis en Uruguay. MSc thesis, PEDECIBA, Facultad de Ciencias, Montevideo

Lercari D, Defeo O (1999) Effects of freshwater discharge in sandy beach populations: the mole crab Emerita brasiliensis in Uruguay. Estuar Coast Shelf Sci 49:457-468

Lewin J, Schaefer T (1983) The role of phytoplankton in surface ecosystems. In: McLachlan A, Erasmus T (eds) Sandy beaches as ecosystems. W Junk, The Hague, p 381-389

Lima M, Brazeiro A, Defeo O (2000) Dynamics of a yellow clam (Mesodesma mactroides) population: recruitment variability, density-dependence and stochastic processes. Mar Ecol Prog Ser 207:97-108

Editorial responsibility: Otto Kinne (Editor),

Oldendorf/Luhe, Germany
Manly BF (1998) Testing for latitudinal and other body-size gradients. Ecol Lett 1:104-111

McLachlan A (1980) Exposed sandy beaches as semi-closed ecosystems. Mar Environ Res 4:59-63

McLachlan A (1983) Sandy beach ecology-a review. In: McLachlan A, Erasmus T (eds) Sandy beaches as ecosystems. W Junk, The Hague, p 321-380

McLachlan A (1990) Dissipative beaches and macrofauna communities on exposed intertidal sands. J Coast Res 6:57-71

McLachlan A, Dugan JE, Defeo O, Ansell AD, Hubbard DM, Jaramillo E, Penchaszadeh P (1996) Beach clam fisheries. Oceanogr Mar Biol Annu Rev 34:163-232

Pauly D, Munro JL (1984) Once more on the comparison of growth in fish and invertebrates. Fishbyte 2(1):21

Pauly D, Moreau J, Abad N (1995) Comparison of age structure and length-converted catch curves of brown trout Salmo trutta in two French rivers. Fish Res 22:197-204

Peluffo E (1998) Distribución espacio-temporal, estructura poblacional y reproducción del tatucito Emerita brasiliensis (Decapoda, Hippidae) en las playas de Cabo Polonio, Rocha, Uruguay. MSc thesis, PEDECIBA, Facultad de Ciencias, Montevideo

Peterson CH (1982) The importance of predation and intraspecific competition in the population biology of two infaunal suspension-feeding bivalves, Protothaca staminea and Chione undatella. Ecol Monogr 52:437-475

Peterson CH, Black R (1987) Resource depletion by active suspension feeders on tidal flats: influence of local density and tidal elevation. Limnol Oceanogr 32:143-166

Ricciardi A, Bourget E (1998) Weight-to-weight conversion factors for marine benthic macroinvertebrates. Mar Ecol Prog Ser 163:245-251

Ricciardi A, Bourget E (1999) Global patterns of macroinvertebrate biomass in marine intertidal communities. Mar Ecol Prog Ser 185:21-35

Santos PJPS (1994) Environmental characterization of sandy beaches in southern Brazil. Neritica (Brazil) 8(1-2):31-45

Silveira EF (1997) Dinâmica populacional de Emerita brasiliensis Schimitt, 1935 em praia arenosa do litoral sul do Brasil (Crustacea, Decapoda Hippidae). MSc thesis, Pontificia Universidade Católica do Rio Grande do Sul, Brazil

Soares AG, Scapini F, Brown AC, McLachlan A (1999) Phenotypic plasticity, genetic similarity and evolutionary inertia in changing environments. J Molluscan Stud 65:136-139

Tam YK, Kornfield I, Ojeda FP (1996) Divergence and zoogeography of mole crabs, Emerita spp. (Decapoda: Hippidae) in the Americas. Mar Biol 125:489-497

Veloso VG, Cardoso RS (1999) Population biology of the mole crab Emerita brasiliensis (Decapoda: Hippidae) at Fora Beach, Brazil. J Crustac Biol 19:147-153

Veloso VG, Cardoso RS (2001) The effects of morphodynamics on the spatial and temporal variation of the macrofauna of three sandy beaches on the Rio de Janeiro State, Brazil. J Mar Biol Assoc UK 81:369-375

Veloso VG, Cardoso RS, de Castro PM, Gutierres LF (1995) Reprodução contínua de Emerita brasiliensis (Decapoda, Hippidae) no Rio de Janeiro, RJ, Brasil. Publ Espec Inst Oceanogr Sao Paulo 11:217-222

Wenner AM, Ricard Y, Dugan J (1987) Hippid crab population structure and food availability on pacific shorelines. Bull Mar Sci 4:221-233

Wenner AM, Dugan JE, Hubbard DM (1993) Sand crab population biology on the California Islands and mainland. In: Hochberg FG (ed) Recent advances in research on the California Islands. 3rd Calif Isls Symp Santa Barbara Museum of Natural History, CA, p 335-348

Zar JH (1999) Biostatistical analysis. Prentice-Hall, New York

Submitted: December 11, 2001; Accepted: April 18, 2002

Proofs received from author(s): July 30, 2002 